\title{
Synthesis of Macrocyclic Hexaoxazole (60TD) Dimers, Containing Guanidine and Amine Functionalized Side Chains, and an Evaluation of Their Telomeric G4 Stabilizing Properties
}

\author{
Keisuke Iida, ${ }^{1}$ Masayuki Tera, ${ }^{1}$ Takatsugu Hirokawa, ${ }^{2}$ Kazuo Shin-ya, ${ }^{3}$ and Kazuo Nagasawa ${ }^{1}$ \\ ${ }^{1}$ Department of Biotechnology and Life Science Faculty of Technology, Tokyo University of Agriculture and Technology (TUAT), \\ Koganei, Tokyo 184-8588, Japan \\ ${ }^{2}$ Computational Biology Research Center, National Institute of Advanced Industrial Science and Technology, \\ Koto-ku, Tokyo 135-0064, Japan \\ ${ }^{3}$ Biological Information Research Center, National Institute of Advanced Industrial Science and Technology, \\ Koto-ku, Tokyo 135-0064, Japan
}

Correspondence should be addressed to Kazuo Nagasawa, knaga@cc.tuat.ac.jp

Received 15 February 2010; Accepted 1 March 2010

Academic Editor: R. Eritja

Copyright ( $) 2010$ Keisuke Iida et al. This is an open access article distributed under the Creative Commons Attribution License, which permits unrestricted use, distribution, and reproduction in any medium, provided the original work is properly cited.

\begin{abstract}
Structure-activity relationship studies were carried out on macrocyclic hexaoxazole (6OTD) dimers, whose core structure stabilizes telomeric G-quadruplexes (G4). Two new 6OTD dimers having side chain amine and guanidine functional groups were synthesized and evaluated for their stabilizing ability against a telomeric G4 DNA sequence. The results show that the 6OTD dimers interact with the DNA to form 1:1 complexes and stabilize the antiparallel G4 structure of DNA in the presence of potassium cation. The guanidine functionalized dimer displays a potent stabilizing ability of the G4 structure, as determined by using a FRET melting assay $\left(\Delta T_{m}=14^{\circ} \mathrm{C}\right)$
\end{abstract}

\section{Introduction}

G-quadruplexes (G4), secondary DNA structures consisting of G-quartet planers in G-rich regions, play significant biological roles for example, control of transcription and telomeric lengths [1-19]. One typical G4 forming DNA sequence is a telomere, which exists at the ends of chromosomes consisting of (TTAGGG) ${ }_{n}$ repeating single-stranded sequences [1-12]. Telomeres protect chromosomes from end to end fusion events, which result in replication of the chromosome (the Hayflick limit) [20]. The telomere repeats are elongated by the reverse transcriptase telomerase, which is overexpressed in most tumor cells. In contrast, telomerase activity is not observed in normal somatic cells [21]. Since the activity of this enzyme is inhibited by the G4 structure of telomeres owing to steric hindrance, small molecules that selectively bind and stabilize the telomeric G4 should be potential anticancer agents. As a result, a number of G4 ligands, inspired by artificial DNA intercalators as well as natural products, have been developed during the past decade [22].

Telomestatin (TMS) is a natural product isolated from Streptomyces anulatus 3533-SV4, which displays one of the most potent telomeric G4 binding activity (Figure 1) [2328]. Interaction analysis has shown that two molecules of TMS induce conversion of telomeric G4 into an antiparallel type by way of an end stacking mode [25-28]. We have recently developed macrocyclic hexaoxazole compounds 6OTD, containing a variety of side chain functional groups, that serve as a novel TMS derivative [29-32]. In addition, by considering the proposed binding mode of TMS with telomeric G4, we have carried out further structural development of dimeric 6OTD derivatives (Figure 1) [33]. The results of molecular dynamics calculations guided the selection of 6OTD dimer 1 that contains an appropriate length of a linker between the monomeric units of 6OTD. Studies showed that dimer 1 binds to telomeric G4 more tightly than do other 6OTD dimers with linkers of shorter or 
longer lengths. One possible structural development strategy to enhance the stabilizing ability of $\mathbf{1}$ against the G4 would be to install cationic functional groups on the side chain [30]. Below, we describe synthesis of new 6OTD dimers 2 and 3 that derivatize 1 but possess cationic amine and guanidine functional groups on their side chains. In addition, the ability of these substances to stabilize telomeric G4 along with their interaction mode was investigated.

\section{Materials and Methods}

2.1. General. Flash chromatography was performed on Silica gel 60 (spherical, particle size $0.040 \sim 0.100 \mu \mathrm{m}$; Kanto). Optical rotations were measured on a JASCO P-2200 polarimeter, using the sodium $\mathrm{D}$ line. ${ }^{1} \mathrm{H}$ and ${ }^{13} \mathrm{C} \mathrm{NMR}$ spectra were recorded on JEOL JNM-ECX 300, 400, and 500. The spectra are referenced internally according to residual solvent signals of $\mathrm{CDCl}_{3}\left({ }^{1} \mathrm{H}\right.$ NMR; $\delta=7.26 \mathrm{ppm},{ }^{13} \mathrm{C}$ NMR $\delta=77.0$; ppm $)$ and DMSO $d-6\left({ }^{1} \mathrm{H}\right.$ NMR; $\delta=$ $2.50 \mathrm{ppm},{ }^{13} \mathrm{C}$ NMR; $\left.\delta=39.5 \mathrm{ppm}\right)$. Data for ${ }^{1} \mathrm{H}$ NMR are recorded as follows: chemical shift $(\delta, \mathrm{ppm})$, multiplicity ( singlet; $\mathrm{d}$, doublet; $\mathrm{m}$, multiplet; br, broad), integration, and coupling constant $(\mathrm{Hz})$. Data for ${ }^{13} \mathrm{C}$ NMR are reported in terms of chemical shift $(\delta$, ppm). Mass spectra were recorded on a JEOL JMS-T100X spectrometer with ESI-MASS mode using methanol as solvent. All oligonucleotides purified were obtained from Sigma Genosys and dissolved in doubledistilled water to be used without further purification. Fluorescence resonance energy transfer (FRET) melting assay was made with an excitation wavelength of $470-505 \mathrm{~nm}$ and a detection wavelength of 523-543 nm using the DNA Engine Opticon 2 Real-Time Cycler PCR detection system (BioRad). CD spectra were recorded on a JASCO810 spectropolarimeter (Jasco, Easton, MD) using a quartz cell of $1 \mathrm{~mm}$ optical path length and an instrument scanning speed of $500 \mathrm{~nm} / \mathrm{min}$ with a response time of $1 \mathrm{~s}$, and over a wavelength range of $220-320 \mathrm{~nm}$. CD spectra are representative of ten averaged scans taken at $25^{\circ} \mathrm{C}$.

\subsection{Synthesis}

Synthesis of 5. To a solution of trioxazole $4(2.1 \mathrm{~g}, 3.6 \mathrm{mmol})$ in MeOH-THF $(1: 1,60 \mathrm{~mL})$ was added $\mathrm{Pd}(\mathrm{OH})_{2} / \mathrm{C}$ $(420 \mathrm{mg})$, and the reaction mixture was stirred at room temperature under hydrogen gas (balloon). After $3 \mathrm{~h}$, the catalyst was removed by filtration through a pad of Celite, and the filtrates were concentrated in vacuo to give amine $\mathbf{5}$, which was used without further purification.

Synthesis of 7 . To a solution of trioxazole $6(2.1 \mathrm{~g}, 3.6 \mathrm{mmol})$ in THF- $\mathrm{H}_{2} \mathrm{O}(3: 1,80 \mathrm{~mL})$ was added $\mathrm{LiOH}(230 \mathrm{mg}$, $5.4 \mathrm{mmol})$ at $0^{\circ} \mathrm{C}$. After stirring at room temperature for $1 \mathrm{~h}$,to the resulting mixture was added $1 \mathrm{~N} \mathrm{HCl}$, to give carboxylic acid 7, which was used without further purification.

Synthesis of 8 . To a solution of amine 5 (abovementioned) in THF- $\mathrm{H}_{2} \mathrm{O}(1: 1)$ was added the carboxylic acid 7 (above- mentioned), $N$-methylmorpholine $(1.2 \mathrm{~mL}, 11 \mathrm{mmol})$, and 4-(4, 6-dimethoxy-1, 3, 5-triazin-2-yl)-4-methylmorpholinium chloride (DMT-MM) $(3.0 \mathrm{~g}, 11 \mathrm{mmol})$, and the mixture was stirred at room temperature for $15 \mathrm{~h}$. To the reaction mixture was added $\mathrm{H}_{2} \mathrm{O}$ and precipitate was formed. This precipitate was collected with filtration using filter paper, to give 8 as a white solid $(3.3 \mathrm{~g}, 3.2 \mathrm{mmol} 89 \% 2$ steps, $\mathrm{mp}$ $\left.=200-203^{\circ} \mathrm{C}\right)$. Spectral data for 8: $[\alpha]^{25}{ }_{\mathrm{D}}=-2.7$ (c 1.1, $\left.\mathrm{CHCl}_{3}-\mathrm{MeOH}(1: 1)\right) ;{ }^{1} \mathrm{H}$ NMR $\left(300 \mathrm{MHz}, \mathrm{CDCl}_{3}\right) \delta 8.43$ (s, $1 \mathrm{H}), 8.35-8.27(\mathrm{~m}, 5 \mathrm{H}), 7.53(\mathrm{~d}, J=8.9 \mathrm{~Hz}, 1 \mathrm{H}), 7.34$ $(\mathrm{m}, 5 \mathrm{H}), 5.98-5.81(\mathrm{~m}, 1 \mathrm{H}), 5.57-5.44(\mathrm{~m}, 2 \mathrm{H}), 5.30(\mathrm{~d}$, $J=18 \mathrm{~Hz}, 1 \mathrm{H}), 5.21(\mathrm{~d}, J=11 \mathrm{~Hz}, 1 \mathrm{H}), 5.15-4.97(\mathrm{~m}$, $2 \mathrm{H}), 4.82(\mathrm{br}, 1 \mathrm{H}), 4.58(\mathrm{~d}, J=5.5 \mathrm{~Hz}, 3 \mathrm{H}), 3.95(\mathrm{~s}, 3 \mathrm{H})$, $3.30-3.01(\mathrm{~m}, 4 \mathrm{H}), 2.25-1.80(\mathrm{~m}, 4 \mathrm{H}), 1.70-1.30(\mathrm{~m}, 17 \mathrm{H})$; ${ }^{13} \mathrm{C}$ NMR $(125 \mathrm{MHz}$, DMSO $d-6) \delta 165.7,165.2,160.9$, $159.8,156.1,155.8,155.7,155.6,155.0,154.4,145.7,142.8$, $141.0,140.9,140.7,137.3,136.6,133.4,133.3,130.1,130.0$, $128.9,128.8,128.3,127.7,117.3,77.3,65.1,64.9,64.7,52.0$, 48.9, 46.8, 31.8, 31.3, 29.2, 28.9, 28.2, 28.1, 22.8, 22.6; HRMS (ESI, $\mathrm{M}+\mathrm{Na}$ ) calcd for $\mathrm{C}_{48} \mathrm{H}_{52} \mathrm{~N}_{10} \mathrm{O}_{15} \mathrm{Na} 1031.3511$, found 1031.3479.

Synthesis of 9. To a solution of bis-trioxazole $8(510 \mathrm{mg}$, $0.50 \mathrm{mmol})$ in DMF-THF $(1: 5,30 \mathrm{~mL})$ was added morpholine $(440 \mu \mathrm{L}, 5.0 \mathrm{mmol})$ and $\mathrm{Pd}\left(\mathrm{PPh}_{3}\right)_{4}(29 \mathrm{mg}, 0.025 \mathrm{mmol})$, and the mixture was stirred at room temperature for $1 \mathrm{~h}$. To the reaction mixture was added ether and precipitate was formed. This precipitate was collected with filtration using filter paper. The solid was purified by column chromatography on silica gel $\left(\mathrm{CHCl}_{3}-\mathrm{MeOH}=9: 1\right)$ to give $9(460 \mathrm{mg}$, $0.50 \mathrm{mmol} 99 \%)$. Spectral data for 9: $[\alpha]^{25}{ }_{\mathrm{D}}=28(c 1.0$, $\left.\mathrm{CHCl}_{3}-\mathrm{MeOH}(1: 1)\right) ;{ }^{1} \mathrm{H}$ NMR $\left(300 \mathrm{MHz}, \mathrm{CDCl}_{3}\right) \delta 8.43$ $(\mathrm{s}, 1 \mathrm{H}), 8.35-8.25(\mathrm{~m}, 5 \mathrm{H}), 7.53(\mathrm{~d}, J=8.9 \mathrm{~Hz}, 1 \mathrm{H}), 7.33(\mathrm{~m}$, $5 \mathrm{H}), 5.56-5.43(\mathrm{~m}, 1 \mathrm{H}), 5.08(\mathrm{br}, 2 \mathrm{H}), 4.80(\mathrm{br}, 1 \mathrm{H}), 4.56$ (br, $1 \mathrm{H}), 4.14-4.05(\mathrm{~m}, 1 \mathrm{H}), 3.95(\mathrm{~s}, 3 \mathrm{H}), 3.26-3.04(\mathrm{~m}, 4 \mathrm{H})$, $2.25-1.75(\mathrm{~m}, 4 \mathrm{H}), 1.73-1.30(\mathrm{~m}, 17 \mathrm{H}) ;{ }^{13} \mathrm{C} \mathrm{NMR}(125 \mathrm{MHz}$, DMSO $d-6) \delta 169.3,165.2,160.9,159.8,156.1,155.9$, $155.7,155.6,154.9,154.4,145.7,142.7,141.0,140.9,140.6$, $140.5,137.3,136.6,133.3,130.0,129.9,128.8,128.5,128.3$, 127.7, 77.3, 65.1, 52.0, 49.4, 46.7, 35.3, 31.3, 29.2, 28.2, 28.1, 22.8, 22.6; HRMS (ESI, $\mathrm{M}+\mathrm{Na}$ ) calcd for $\mathrm{C}_{44} \mathrm{H}_{48} \mathrm{~N}_{10} \mathrm{O}_{13} \mathrm{Na}$ 947.3300, found 947.3308 .

Synthesis of 10. To a solution of bis-trioxazole $9(2.2 \mathrm{~g}$, $2.4 \mathrm{mmol})$ in THF- $\mathrm{H}_{2} \mathrm{O}(3: 1,200 \mathrm{~mL})$ was added lithium hydroxide $(300 \mathrm{mg}, 7.2 \mathrm{mmol})$, and the mixture was stirred at room temperature for $2 \mathrm{~h}$. To the reaction mixture was added $1 \mathrm{~N} \mathrm{HCl}$, and the resulting mixture was concentrated in vacuo. To the residual solution in $\mathrm{DMF}-\mathrm{CH}_{2} \mathrm{Cl}_{2}$ (1 : 2, $800 \mathrm{~mL})$ was added DMAP $(1.5 \mathrm{~g}, 12 \mathrm{mmol})$, diisopropylethylamine $(2.0 \mathrm{~mL}, 12 \mathrm{mmol})$, and DPPA $(2.6 \mathrm{~mL}$, $12 \mathrm{mmol}$ ), and the resulting mixture was stirred for $22 \mathrm{~h}$ at $90^{\circ} \mathrm{C}$. To the reaction mixture was added $\mathrm{H}_{2} \mathrm{O}$ and the organic layer was extracted with ethyl acetate. The extracts were washed with brine, dried over $\mathrm{MgSO}_{4}$, filtered, and concentrated in vacuo. The residue was purified by column chromatography on silica gel (ethyl acetate 100\%) to give 10 as a white solid $\left(1.7 \mathrm{~g}, 1.9 \mathrm{mmol} 79 \%, \mathrm{mp}=220-225^{\circ} \mathrm{C}\right.$ 


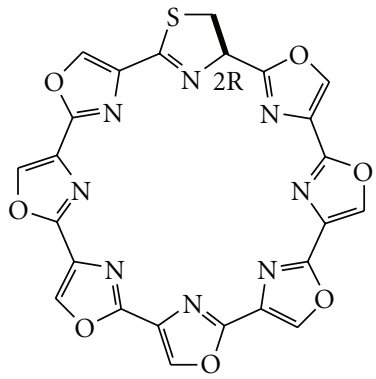

Telomestatin (TMS)

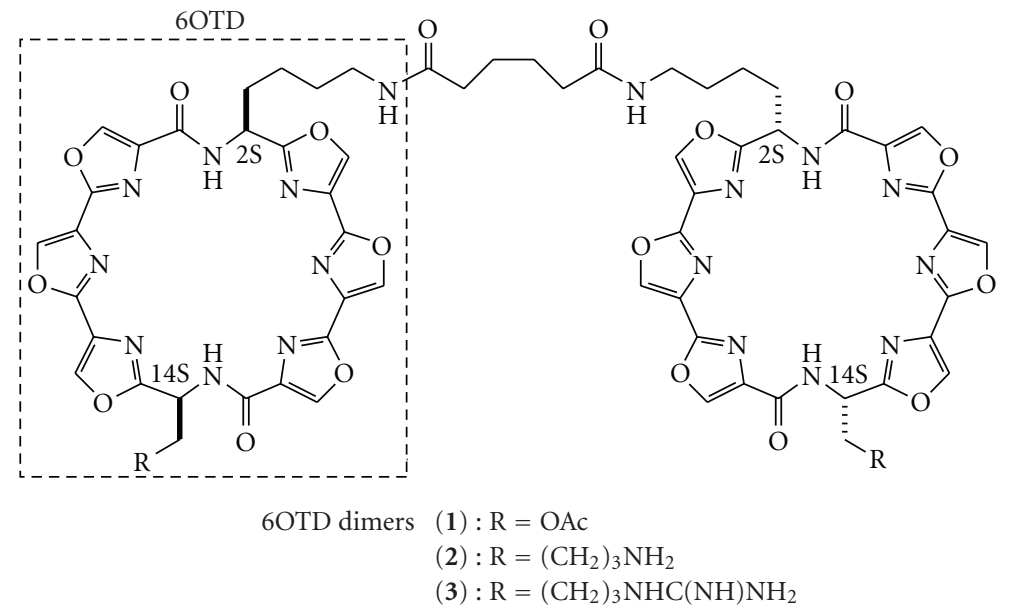

FIgURE 1: Structures of telomestatin and 6OTD dimers.

dec). Spectral data for 10: $[\alpha]^{25}=-12\left(c\right.$ 0.4, $\mathrm{CHCl}_{3}-$ $\mathrm{MeOH}(1: 1)) ;{ }^{\mathrm{H}} \mathrm{H}$ NMR $\left(400 \mathrm{MHz}, \mathrm{CDCl}_{3}\right) \delta 8.54(\mathrm{~d}, J$ $=7.3 \mathrm{~Hz}, 2 \mathrm{H}), 8.25-8.16(\mathrm{~m}, 6 \mathrm{H}), 7.36-7.27(\mathrm{~m}, 5 \mathrm{H}), 5.47-$ $5.37(\mathrm{~m}, 2 \mathrm{H}), 5.05$ (br, $2 \mathrm{H}), 4.89$ (br, $1 \mathrm{H}), 4.59$ (br, $1 \mathrm{H})$, 3.22-2.98 (m, 4H), 2.30-1.89 (m, 4H), 1.62-1.18 (m, 17H); ${ }^{13} \mathrm{C}$ NMR $\left(100 \mathrm{MHz}, \mathrm{CDCl}_{3}\right) \delta 164.8,164.7,161.2,159.9$, $159.8,156.3,156.0,155.9,154.6,141.0,140.9,139.1,138.4$, $136.9,136.8,136.6,130.9,129.6,128.4,128.1,128.0,79.0$, 66.5, 47.8, 47.7, 40.7, 40.3, 34.6, 29.5, 29.2, 28.4, 21.9, 21.8; HRMS (ESI, $\mathrm{M}+\mathrm{Na}$ ) calcd for $\mathrm{C}_{43} \mathrm{H}_{44} \mathrm{~N}_{10} \mathrm{O}_{12} \mathrm{Na} 915.3038$, found 915.2999.

Synthesis of 11. To a solution of macrocyclic bis-amide $10(200 \mathrm{mg}, 220 \mu \mathrm{mol})$ in $\mathrm{MeOH}(50 \mathrm{~mL})$ was added $\mathrm{Pd}(\mathrm{OH})_{2} / \mathrm{C}(80 \mathrm{mg})$ and the reaction mixture was stirred at room temperature under hydrogen (balloon). After $5 \mathrm{~h}$, the reaction mixture was filtered through a pad of Celite, and the filtrates were concentrated in vacuo. To the residual solution in DMF-MeCN $(1: 1,4.0 \mathrm{~mL})$ was added diisopropylethylamine $(190 \mu \mathrm{L}, 1.1 \mathrm{mmol})$ and adipoyl chloride $(16 \mu \mathrm{L}, 110 \mu \mathrm{mol})$, and the mixture was stirred at room temperature for $11 \mathrm{~h}$. The reaction mixture was concentrated in vacuo, and the residue was acidified with $0.1 \mathrm{~N} \mathrm{HCl}$ and extracted with $\mathrm{CHCl}_{3}$. The organic layer was dried over $\mathrm{MgSO}_{4}$, filtrated, and concentrated in vacuo. The residue was purified by column chromatography on silica gel $\left(\mathrm{CHCl}_{3}-\right.$ AcOEt-MeOH $=3: 2: 1)$ to give $11(51 \mathrm{mg}, 31 \mu \mathrm{mol}, 28 \%)$. Spectral data for 11: $[\alpha]^{25}{ }_{\mathrm{D}}=-11\left(c 0.95, \mathrm{CHCl}_{3}-\mathrm{MeOH}\right.$ $(1: 1)) ;{ }^{1} \mathrm{H}$ NMR $\left(500 \mathrm{MHz}, \mathrm{CDCl}_{3}\right) \delta 8.67-8.48(\mathrm{~m}, 4 \mathrm{H})$, 8.27-8.15 (m, 12H), $6.38(\mathrm{br}, 2 \mathrm{H}), 5.47-5.38(\mathrm{~m}, 4 \mathrm{H}), 4.84$ (br, 2H), 3.30-2.98 (m, 8H), 2.15-1.90 (m, 12H), 1.65$1.10(\mathrm{~m}, 38 \mathrm{H}) ;{ }^{13} \mathrm{C}$ NMR $\left(125 \mathrm{MHz}, \mathrm{CDCl}_{3}\right) \delta 173.0,164.9$, $164.8,159.8,159.7,156.2,156.1,156.0,154.7,154.6,141.0$, $140.9,139.5,139.3,138.7,138.6,136.9,136.8,130.8,129.5$, $129.3,78.9,47.8,47.7,40.3,38.9,36.0,34.5,34.3,29.7,29.5$, 28.8, 28.4, 25.1, 21.9, 21.7; HRMS (ESI, M + Na) calcd for $\mathrm{C}_{76} \mathrm{H}_{82} \mathrm{~N}_{20} \mathrm{O}_{22} \mathrm{Na}$ 1649.5810, found 1649.5811 .

Synthesis of 2. A solution of $11(50 \mathrm{mg}, 31 \mu \mathrm{mol})$ in $\mathrm{CH}_{2} \mathrm{Cl}_{2}$ TFA $(95: 5,25 \mathrm{~mL})$ was stirred at room temperature for $2 \mathrm{~h}$. The reaction mixture was concentrated in vacuo to give 2 as a white solid (50 mg, $30 \mu \mathrm{mol}, 98 \%, \mathrm{mp}=225-230^{\circ} \mathrm{C} \mathrm{dec}$ ). Spectral data for 2: $[\alpha]^{25}=72\left(\right.$ c $\left.0.3, \mathrm{CHCl}_{3}-\mathrm{MeOH}(1: 1)\right)$; ${ }^{1} \mathrm{H}$ NMR $(500 \mathrm{MHz}$, DMSO $d-6) \delta 9.15-9.08(\mathrm{~m}, 8 \mathrm{H}), 8.95-$ $8.89(\mathrm{~m}, 4 \mathrm{H}), 8.38(\mathrm{~d}, J=6.9 \mathrm{~Hz}, 2 \mathrm{H}), 8.30(\mathrm{~d}, J=6.9 \mathrm{~Hz}$, $1 \mathrm{H}), 7.80-7.53(\mathrm{~m}, 6 \mathrm{H}), 5.50-5.35(\mathrm{~m}, 4 \mathrm{H}), 2.98-2.89(\mathrm{~m}$, $4 \mathrm{H}), 2.78-2.89(\mathrm{~m}, 4 \mathrm{H}), 2.15-1.85(\mathrm{~m}, 12 \mathrm{H}), 1.55-1.00(\mathrm{~m}$, $20 \mathrm{H}) ;{ }^{13} \mathrm{C}$ NMR $(125 \mathrm{MHz}$, DMSO $d-6) \delta 171.7,164.5$, $164.3,158.8,158.7,155.6,154.5,142.5,141.9,141.8,141.1$, $136.0,129.8,129.7,128.5,128.4,47.4,47.3,38.6,38.1,35.1$, 
<smiles>CCNC(CCCCNC(=O)c1ccccc1)c1nc(-c2nc(-c3nc(C(=O)OC)co3)co2)co1</smiles><smiles>[R20]C(=O)c1coc(-c2coc(-c3coc(C(CCCNC(=O)OCc4ccccc4)NCCCC)n3)n2)n1</smiles>

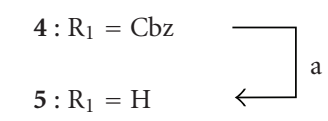
$6: \mathrm{R}_{2}=\mathrm{Me}$
$7: \mathrm{R}_{2}=\mathrm{H} \longleftarrow \mathrm{b}$

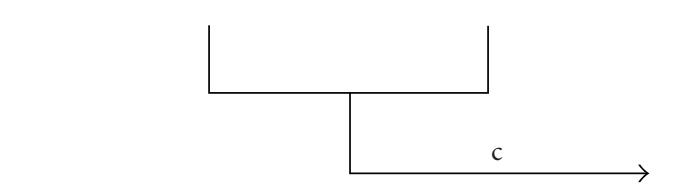<smiles>CC(C)NC(=O)c1nc(-c2coc(-c3coc(-c4coc(-c5coc(-c6coc(C(CCCCNC(=O)OCc7ccccc7)c7nc(C(=O)NC(CCCCNC(=O)OC(C)(C)C)c8ccccc8)co7)n6)n5)n4)n3)n2)co1</smiles>
BocHN<smiles>[R11]NC(CCCCNC(=O)OCc1ccccc1)c1nc(-c2nc(-c3nc(C(=O)NC(CCCCN)c4nc(-c5nc(-c6nc(C(=O)OC)co6)co5)co4)co3)co2)co1</smiles><smiles>[101In]</smiles>

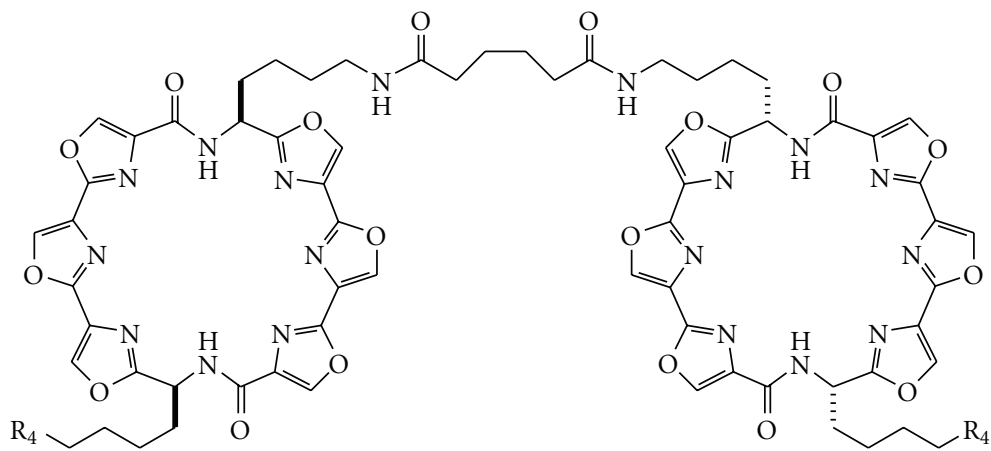<smiles></smiles>
$11: \mathrm{R}_{4}=\mathrm{NHBoc}$ $2: \mathrm{R}_{4}=\mathrm{NH}_{2}$ $12: \mathrm{R}_{4}=\mathrm{NHC}(\mathrm{NBoc}) \mathrm{NHBoc}$ $3: \mathrm{R}_{4}=\mathrm{NHC}(\mathrm{NH}) \mathrm{NH}_{2}$

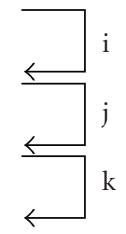

Scheme 1: Synthesis of 6OTD dimers. (a) $\mathrm{Pd}(\mathrm{OH})_{2} / \mathrm{C}, \mathrm{H}_{2}$, THF-MeOH; (b) LiOH $\cdot \mathrm{H}_{2} \mathrm{O}$, THF- $\mathrm{H}_{2} \mathrm{O}$; (c) DMT-MM, $N$-methylmorpholine, THF- $\mathrm{H}_{2} \mathrm{O}, 89 \%$ over 2 steps from 4 and 6; (d) $\mathrm{Pd}\left(\mathrm{PPh}_{3}\right)_{4}$, morpholine, DMF-THF 99\%; (e) $\mathrm{LiOH} \cdot \mathrm{H}_{2} \mathrm{O}, \mathrm{THF}-\mathrm{H}{ }_{2} \mathrm{O}$; (f) $N, N-$ diisopropylethylamine, DMAP, DPPA, DMF- $\mathrm{CH}_{2} \mathrm{Cl}_{2}, 78 \%$ over 2 steps from 9; (g) $\mathrm{Pd}(\mathrm{OH})_{2} / \mathrm{C}, \mathrm{H}_{2}, \mathrm{MeOH}$; h) N,N-diisopropylethylamine, adipoyl chloride, 28\% over 2 steps from 10; (i) TFA, $\mathrm{CH}_{2} \mathrm{Cl}_{2} 98 \%$; (j) $\mathrm{Et}_{3} \mathrm{~N}, \mathrm{HgCl}_{2}$, 1,3-bis(tert-butoxycarbonyl)-2-methyl-2-thiopseudourea; (k) TFA, $\mathrm{CH}_{2} \mathrm{Cl}_{2}, 42 \%$; Boc = tert-butoxycarbonyl, $\mathrm{Cbz}=$ benzyloxycarbonyl, DMT-MM = 4-(4,6-dimethoxy-1,3,5-triazin-2-yl)-4methylmorpholinium chloride, DMAP = 4-dimethylaminopyridine, DPPA = diphenylphosphoryl azide, TFA = trifluoroacetic acid.

33.1, 28.7, 26.7, 24.9, 21.3, 20.8; HRMS (ESI, M + H) calcd for $\mathrm{C}_{66} \mathrm{H}_{67} \mathrm{~N}_{20} \mathrm{O}_{18}$ 1427.4942, found 1427.4961.
Synthesis of 12. To a solution of $2(50 \mathrm{mg}, 30 \mu \mathrm{mol})$ in $\mathrm{MeOH}$ $(5.0 \mathrm{~mL})$ was added Amberlyst A-26(OH) ion-exchange 


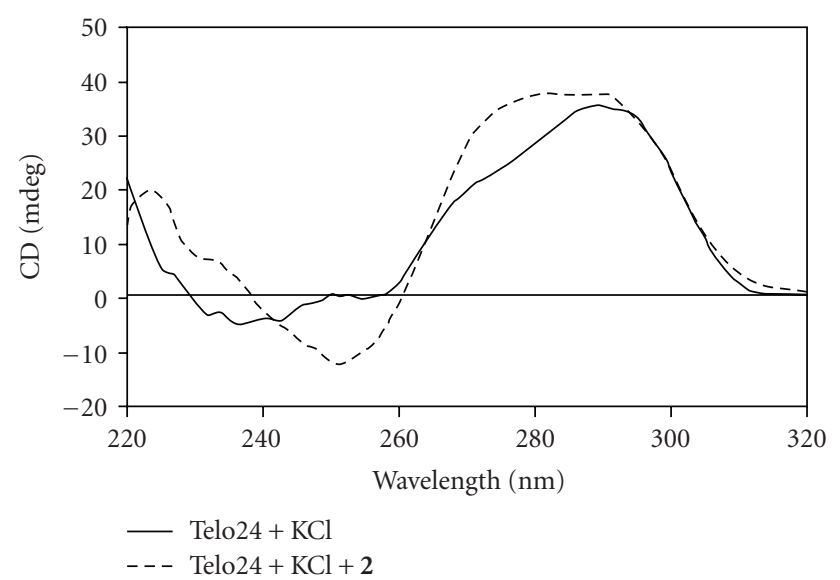

(a)

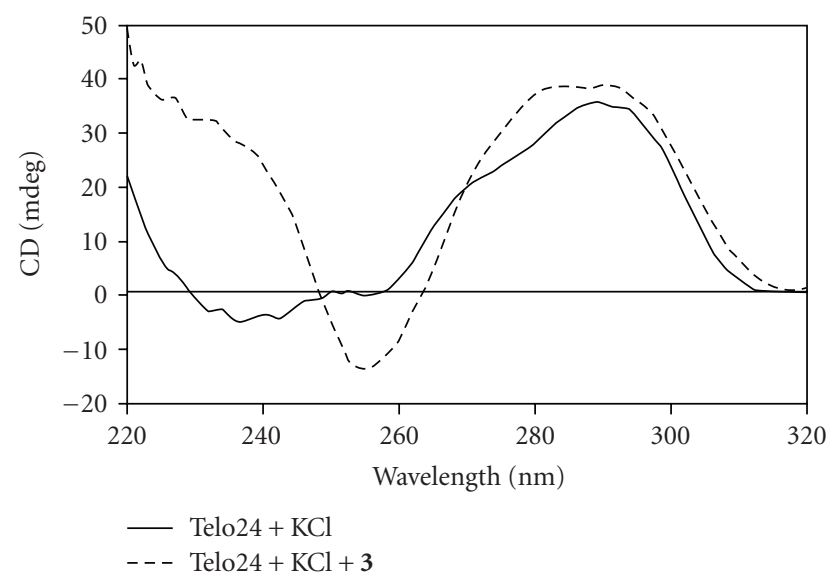

(b)

Figure 2: CD spectra of telo24 $(10 \mu \Delta \mathrm{M})$ in Tris-HCl buffer (50 mM, pH 7.0) with $\mathrm{KCl}(100 \mathrm{mM})$ and/or ligands $(50 \mu \mathrm{M})$. (a) solid line: telo $24+\mathrm{KCl}$; dashed line: telo $24+\mathrm{KCl}+2$. (b) solid line: telo24 + KCl; dashed line: telo24 $+\mathrm{KCl}+3$.

resin, and the mixture was stirred for 30 minutes. The resulting mixture was filtered through a cotton with $\mathrm{MeOH}$, and the filtrates were concentrated in vacuo. To a residual solution of 2 in $\operatorname{DMF}(5.0 \mathrm{~mL})$ was added diisopropylethylamine $(52 \mu \mathrm{L}, 0.31 \mathrm{mmol}), \mathrm{HgCl}_{2}(50 \mathrm{mg}$, $0.18 \mathrm{mmol}$ ), and 1,3-Bis(tertbutoxycarbonyl)-2-methyl-2thiopseudourea $(66 \mathrm{mg}, 0.18 \mathrm{mmol})$, and the mixture was stirred for $1 \mathrm{~h}$ at room temperature. To the reaction mixture was added $\mathrm{H}_{2} \mathrm{O}$, and the organic layer was extracted with ethyl acetate. The extracts were dried over $\mathrm{MgSO}_{4}$, filtered, and concentrated in vacuo. The residue was chromatographed on silica gel $\left(\mathrm{CHCl}_{3}\right.$-ethyl acetate- $\mathrm{MeOH}=$ $3: 2: 1$ ) to give 12 as a white solid ( $30 \mathrm{mg}, 16 \mu \mathrm{mol}, 52 \%$ ). Spectral data for 12: $[\alpha]^{25}{ }_{\mathrm{D}}=3.8\left(c 1.4, \mathrm{CHCl}_{3}-\mathrm{MeOH}\right.$ $(1: 1)) ;{ }^{1} \mathrm{H}$ NMR $\left(500 \mathrm{MHz}, \mathrm{CDCl}_{3}\right) \delta 11.5$ (br, 2H), 8.578.48 (m, 4H), 8.30-8.17 (m, 14H), 6.17 (br, 2H), 5.45-5.36 (m, 4H), 3.41-3.32 (m 4H), 3.28-3.10 (m, 4H), 2.20-1.88 $(\mathrm{m}, 12 \mathrm{H}), 1.65-1.20(\mathrm{~m}, 56 \mathrm{H}) ;{ }^{13} \mathrm{C} \mathrm{NMR}\left(125 \mathrm{MHz}, \mathrm{CDCl}_{3}\right)$ $\delta 172.9,164.8,164.7,163.5,159.9,159.7,156.1,156.0,154.7$, $154.6,153.2,141.0,140.9,139.3,139.2,138.6,138.5,136.9$,
$136.8,130.8,129.6,129.5,82.9,79.1,47.7,47.6,40.5,39.1$, $36.0,34.7,28.7,28.6,28.2,28.0,25.0,22.1,22.0$; HRMS (ESI, $\mathrm{M}+\mathrm{Na}$ ) calcd for $\mathrm{C}_{88} \mathrm{H}_{102} \mathrm{~N}_{24} \mathrm{O}_{26} \mathrm{Na} 1933.7295$, found 1933.7332 .

Synthesis of 3. A solution of $12(29 \mathrm{mg}, 31 \mu \mathrm{mol})$ in $\mathrm{CH}_{2} \mathrm{Cl}_{2}$ TFA $(3: 1,2.0 \mathrm{~mL})$ was stirred at room temperature for $2 \mathrm{~h}$. To the reaction mixture was added ether and precipitate was formed. This precipitate was collected with filtration using filter paper, to give 3 as a white solid ( $20 \mathrm{mg}, 12 \mu \mathrm{mol}, 80 \%$, $\left.\mathrm{mp}=220-225^{\circ} \mathrm{C} \mathrm{dec}\right)$. Spectral data for 3: $[\alpha]^{25}{ }_{\mathrm{D}}=-18$ (c $\left.0.75, \mathrm{CHCl}_{3}-\mathrm{MeOH}(1: 1)\right) ;{ }^{1} \mathrm{H}$ NMR (400 MHz, DMSO $d-6) \delta 9.14-9.08(\mathrm{~m}, 8 \mathrm{H}), 8.94-8.90(\mathrm{~m}, 4 \mathrm{H}), 8.37(\mathrm{~d}, J$ $=7.3 \mathrm{~Hz}, 1 \mathrm{H}), 8.32(\mathrm{~d}, J=7.3 \mathrm{~Hz}, 1 \mathrm{H}), 7.75-7.69(\mathrm{~m}, 2 \mathrm{H})$, 7.51-7.45 (m, 2H), 5.48-5.37 (m, 4H), 3.08-2.90 (m, 8H), 2.15-1.84 (m, 12H), $1.50-1.00(\mathrm{~m}, 20 \mathrm{H}) ;{ }^{13} \mathrm{C}$ NMR $(125$ MHz, DMSO $d-6) \delta 171.7,164.5,164.4,158.8,158.7,156.7$, $155.7,155.6,154.5,142.5,141.8,141.1,136.0,129.8,129.7$, $128.5,128.4,47.4,40.5,38.1,35.1,33.4,33.3,28.7,28.2$, 24.9, 21.3, 21.0; HRMS (ESI, $\mathrm{M}+\mathrm{H}$ ) calcd for $\mathrm{C}_{68} \mathrm{H}_{71} \mathrm{~N}_{24} \mathrm{O}_{18}$ 1511.5378 , found 1511.5368 .

2.3. FRET Melting Assay. FRET melting assays were performed as reported methods $[34,35]$. The dual fluorescently labeled oligonucleotides Flu-telo21 5'-FAM[GGG(TTAGGG)3]-TAMRA-3' and Flu-ds26 5'-FAM[(TA)2GC(TA)2T6(TA)2GC(TA)2]-TAMRA-3' were used in this protocol. The donor fluorophore was 6-carboxyfluorescein, FAM, and the acceptor fluorophore was 6-carboxytetramethylrhodamine, TAMRA. The oligonucleotides were initially dissolved as a $100 \mu \mathrm{M}$ stock solution in MilliQ water; further dilutions were carried out in $60 \mathrm{mM}$ potassium cacodylate buffer ( $\mathrm{pH}$ 7.4). Dual-labeled DNA was annealed at a concentration of $400 \mathrm{nM}$ by heating at $94^{\circ} \mathrm{C}$ for 5 minutes followed by cooling to room temperature. We added the different concentrations of ligands into different samples, using a total reaction volume of $40 \mu \mathrm{L}$, with $200 \mathrm{nM}$ of labelled oligonucleotide. Then we lay them at $25^{\circ} \mathrm{C}$. Following experiments should keep the temperature procedure in real-time PCR and procedure was finished as following: $25^{\circ} \mathrm{C}$ for 5 minutes, then a stepwise increase of $1^{\circ} \mathrm{C}$ every minute from $25^{\circ} \mathrm{C}$ to reach $99^{\circ} \mathrm{C}$. During the procedures, we measured the FAM after each stepwise.

2.4. CD Spectroscopy. The $10 \mu \mathrm{M}$ oligonucleotide of telo24: ([TTAGGG $]_{4}$ ) was dissolved in Tris- $\mathrm{HCl}$ buffer $(50 \mathrm{mM}$, $\mathrm{pH} 7.0$ ) and the solution was heated to $90^{\circ} \mathrm{C}$ for 5 minutes, then slowly cooled to $25^{\circ} \mathrm{C}$. G4 ligands were diluted from $10 \mathrm{mM}$ stock solutions to give a concentration of $1 \mathrm{mM}$ with water and added into the oligonucleotide samples at $50 \mu \mathrm{M}$ (the $10 \mathrm{mM}$ stock solutions of 2 and 3 were made in DMSO).

2.5. ESI-MASS Spectrometry. ESI-MASS spectra were recorded in a negative-ion mode with JEOL JMST100X spectrometer. The direct-infusion flow rate was $5.0 \mu \mathrm{L} \mathrm{min}{ }^{-1}$. All experiments were performed in $20 \mathrm{mM}$ 


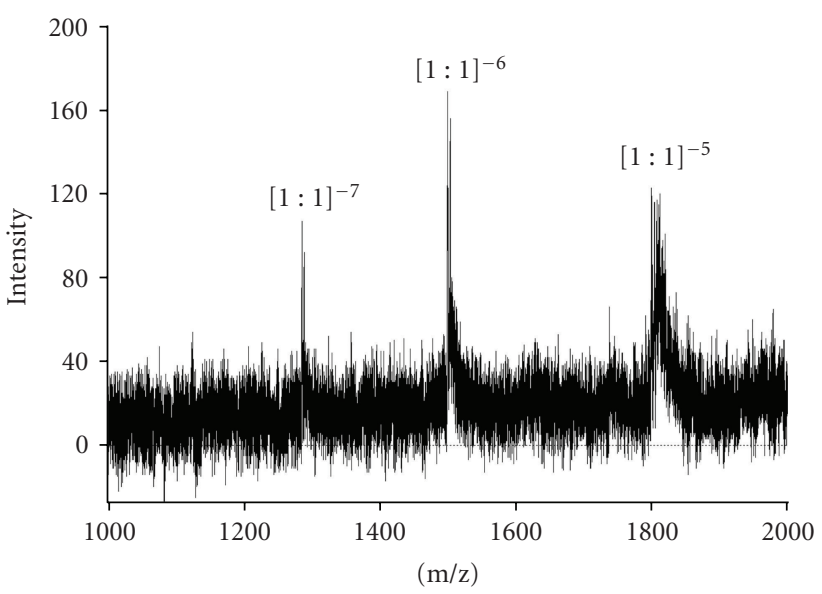

Exact mass of ss-telo24 : 7571.27

Exact mass of $2: 1426.47$

$[1: 1]^{5-}$ calcd for 1798.55 found 1799.64

$[1: 1]^{6-}$ calcd for 1498.62 found 1499.59

$[1: 1]^{7-}$ calcd for 1284.39 found 1285.21

(a)

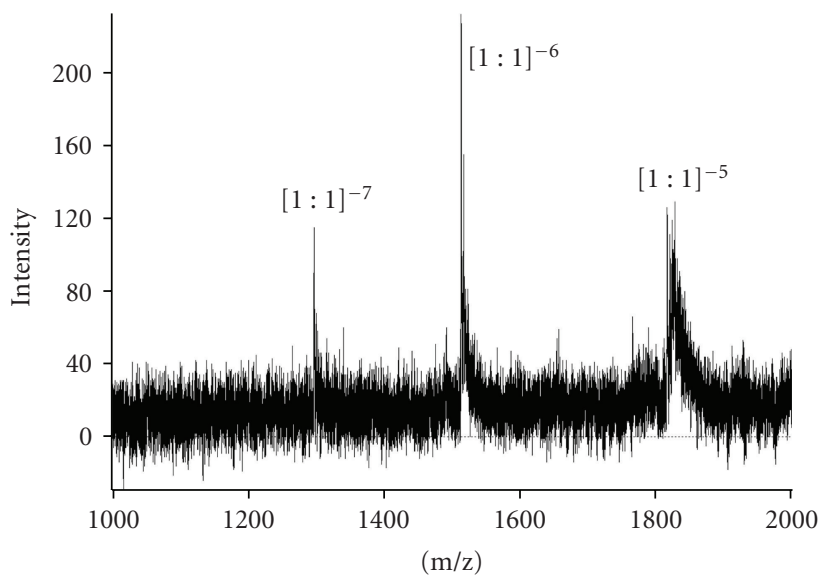

Exact mass of ss-telo24 : 7571.27

Exact mass of $3: 1510.53$

$[1: 1]^{5-}$ calcd for 1815.36 found 1816.56

$[1: 1]^{6-}$ calcd for 1512.63 found 1513.71

$[1: 1]^{7-}$ calcd for 1296.4 found 1297.38

(b)

Figure 3: ESI-MASS spectra of $10 \mu \mathrm{M}$ telo24 with a $40 \mu \mathrm{M}$ ligands 2 (a) and 3 (b).

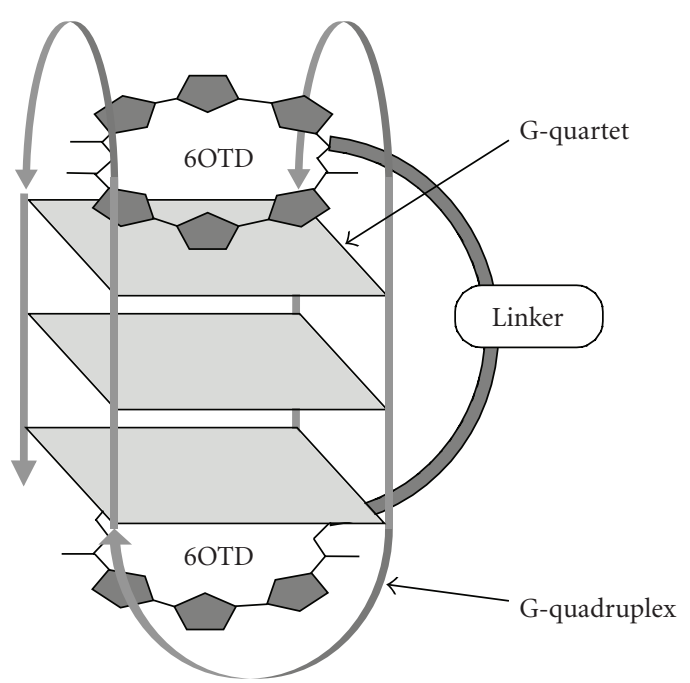

FIGURE 4: Plausible binding mode of the 6OTD dimers with telo24 [33].

$\mathrm{NH}_{4} \mathrm{OAc}$ containing $10 \mu \mathrm{M}$ of telo 24 and $40 \mu \mathrm{M}$ of 2 and 3 . Methanol (15\%) was added just before injection.

\section{Results and Discussion}

3.1. Synthesis of 6OTD Dimers 2 and 3. The 6OTD dimers 2 and 3 were synthesized by using the sequences as shown in Scheme 1. Trioxazoles 4 and $\mathbf{6}$ were synthesized starting with L-serine and L-lysine, respectively by using the previously reported procedure $[29,30,36-38]$. The $\mathrm{Cbz}$ group of 4 was removed by treatment with hydrogen in the presence of $\mathrm{Pd}(\mathrm{OH})_{2} / \mathrm{C}$ to give amine 5. Hydrolysis of the ester group in $\mathbf{6}$ with lithium hydroxide followed by coupling of the resulting acid with amine 5 using DMT-MM [39] gave the bis-trioxazole amide 8 . Cleavage of the allyloxycarbonyl group in $\mathbf{8}$ and hydrolysis of the ester group produced an amino acid, which was subjected to macrocyclization under high dilution conditions $(5 \mathrm{mM})$ to give 6OTD 10. The $\mathrm{Cbz}$ group in $\mathbf{1 0}$ was removed with hydrogen in the presence of $\mathrm{Pd}(\mathrm{OH})_{2} / \mathrm{C}$ to give corresponding amine. The procedure for synthesis of dimer 11 involved coupling of the amine with adipoyl chloride. Bis-amine 2 was obtained by removal of the Boc group of $\mathbf{1 1}$ with TFA. Preparation of the guanidine derivative 3 was carried out by guanidination of the amine moiety in 2 by using 1,3-bis(tert-butoxycarbonyl)-2-methyl2-thiopseudourea followed by deprotection of Boc group with TFA.

3.2. Binding Properties of 2 and $\mathbf{3}$ toward Telomeric G4. With the desired 6OTD dimers 2 and 3 in hand, their mode of interaction with the telomeric DNA (telo24) was investigated. Firstly, conformational changes of telo24, induced by these substances were evaluated using circular dichroism (CD) spectroscopy. Upon treatment of telo24 with 6OTD dimers 2 and $3(50 \mu \mathrm{M})$ in the presence of potassium chloride $(100 \mathrm{mM})$, the mixed-type structure induced by potassium cation (solid line in Figure 2) is transformed to a typical antiparallel-type G4 structure (dashed line in Figure 2) $[28,40]^{1}$. The binding stoichiometries of the complexes formed between the telo24 and ligands and 3 ( molar ratio $=1: 4$ ) were determined by using ESI-MASS spectrometric analysis $[41,42]$. In both cases, only mass peaks that correspond to 1:1 complexes of both 2 and 3 with telo24 were observed (at the 7-, 6- or in the 5-charge states). Since these interaction modes are the same as that of 6OTD dimer $\mathbf{1}$, the newly synthesized 6OTD dimers 2 and 3 


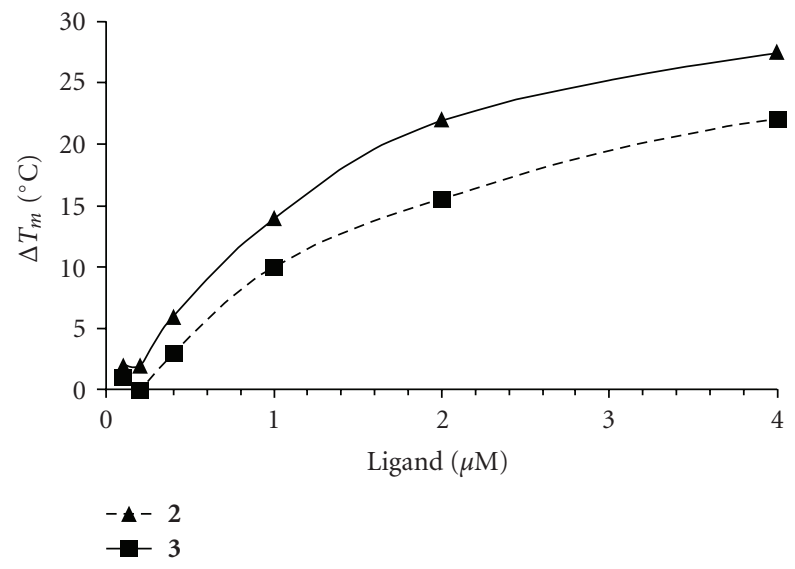

(a)

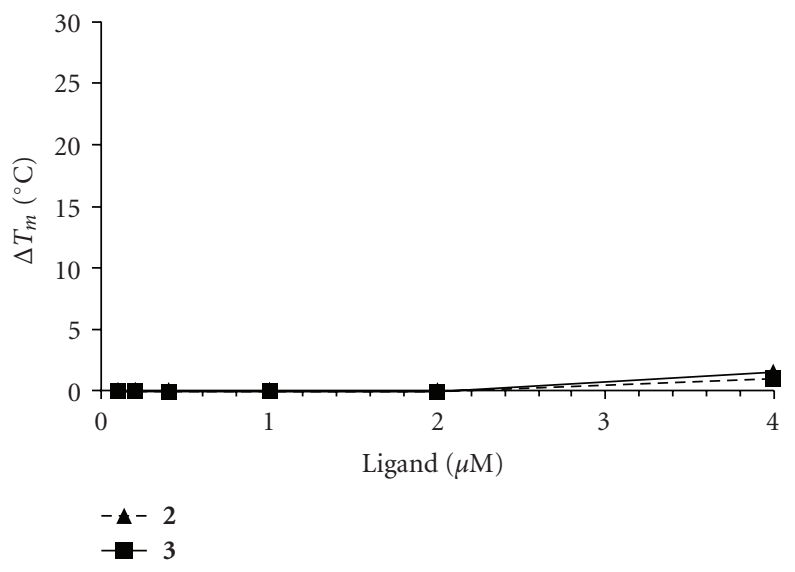

(b)

FIgure 5: $\Delta T_{m}$ values of $0.2 \mu \mathrm{M}$ Flu-telo21 (a) and Flu-ds26 (b) in the presence of ligands 2 (solid line) and 3 (dashed line).

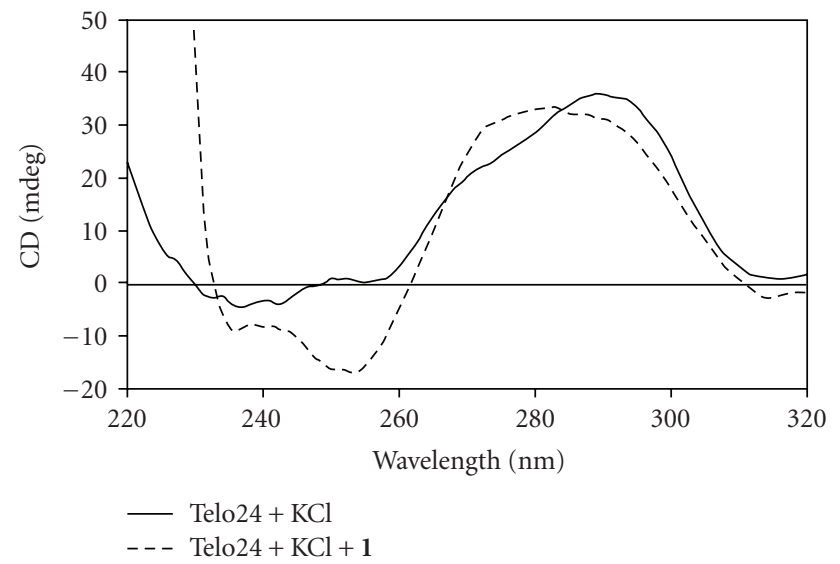

Figure 6

appear to interact with telo24 through an end stacking mode using two 6OTD moieties in a manner similar to that of TMS and/or 6OTD dimer 1 (Figures 4 and 6) [33 $]^{2,3}$.

The ability to stabilize the G4 structure of telo24 by 6OTD dimers 2 and 3 was evaluated by employing a fluorescence resonance energy transfer -(FRET-) based assay $[34,35]$. The $\Delta T_{m}$ values of labeled oligonucleotide flutelo21 with 2 and 3 at a concentration of $1 \mu \mathrm{M}$, which corresponds to 5 equivalents, are 10 and $14^{\circ} \mathrm{C}$, respectively (Figure 5(a) and Table 1). Since under the same conditions the $\Delta T_{m}$ value for 1 was $12^{\circ} \mathrm{C}$, among the substances explored to date guanidine 3 is a potent stabilizer of the G4 structure 4 . This stabilization effect is likely caused by the attractive interaction between positively charged guanidinium residue and anionic phosphates backbone of the telomeric G4. Interactions of the ligands with the duplex form of flu-ds26 were also investigated by using the same protocol (Figure 5(b) and Table 1). The observation that no differences in the $\Delta T_{m}$ values exist in the presence or absence of dimers 2 and suggests that these ligands are selective for the telomere DNA sequence.
TABLE 1: $\Delta T_{m}$ values by FRET melting assay.

\begin{tabular}{lcc}
\hline G4 ligands & $\mathbf{2}$ & $\mathbf{3}$ \\
& $\Delta T_{m}$ at $1 \mu \mathrm{M}$ G4 ligands $\left(\Delta T_{m} /{ }^{\circ} \mathrm{C}\right)$ & \\
\hline Flu-telo21 & 10 & 14 \\
Flu-ds26 & 0 & 0 \\
\hline
\end{tabular}

\section{Conclusions}

In summary, the efforts described above have led to the design and syntheses of $\mathbf{2}$ and $\mathbf{3}$, two novel macrocyclic hexaoxazole dimeric derivatives of 6OTD that have amine and guanidine groups in their respective side chains. These compounds, together with 6OTD dimer acetate 1 , were found to induce a change of the telomeric DNA sequence of telo24 into an antiparallel structure through the formation of $1: 1$ complexes with the DNA. The guanidine functionalized 6OTD dimer 3 was determined to have the greatest ability to stabilize the telomere DNA sequence. Also, both dimers selectively bind to the telomeric DNA sequence and not double-stranded DNA. Further studies, aimed at the structural development of 6OTD dimers with different linkers, are currently underway.

\section{Acknowledgments}

This work was supported in part by the Novartis Foundation (Japan) for the Promotion of Science, a Grant-in-Aid for Exploratory Research (21655060), and a Grant under the Industrial Technology Research Grant Program (01A04006b) from the New Energy and Industrial Technology Development Organization (NEDO) of Japan. Keisuke Iida and Masayuki Tera are grateful for a JSPS Research Fellowship for Young Scientists and a grant under the education program "Human Resource Development Program for Scientific Powerhouse" provided through Tokyo University of Agriculture \& Technology. 


\section{Endnotes}

1. Telomeric antiparallel intramolecular G-quadruplexes have characteristic CD spectra consisting of a positive peak at $290 \mathrm{~nm}$ and a negative peak at $260 \mathrm{~nm}[28,40]$.

2. A similar conformational change was observed for 6OTD dimer 1 by using CD spectroscopic analysis of a solution of $10 \mu \mathrm{M}$ of telo 24 in the presence of potassium chloride $(100 \mathrm{mM})$ and Tris- $\mathrm{HCl}$ buffer (50 mM, pH 7.0) as shown in Figure 6 (solid line: telo24 $+\mathrm{KCl}$, dashed line: telo24 $+\mathrm{KCl}+\operatorname{dimer} \mathbf{1})$.

3. The 6OTD dimer 1 also interacts with telo24 by forming $1: 1$ complex based on ESI-MASS analysis [33].

4. Under the same measurement conditions, the $\Delta T_{m}$ values in the presence of $1 \mu \mathrm{M} 1$ are $12^{\circ} \mathrm{C}$ (Flu-telo21) and $0^{\circ} \mathrm{C}$ (Flu-ds26), respectively.

\section{References}

[1] D. J. Patel, A. T. Phan, and V. Kuryavyi, "Human telomere, oncogenic promoter and 5'-UTR G-quadruplexes: diverse higher order DNA and RNA targets for cancer therapeutics," Nucleic Acids Research, vol. 35, no. 22, pp. 7429-7455, 2007.

[2] S. Neidle and G. N. Parkinson, "Quadruplex DNA crystal structures and drug design," Biochimie, vol. 90, no. 8, pp. 1184-1196, 2008.

[3] A. T. Phan, "Human telomeric G-quadruplex: structures of DNA and RNA sequences," FEBS Journal, vol. 277, no. 5, pp. 1107-1117, 2010.

[4] Y. Wang and D. J. Patel, "Solution structure of the human telomeric repeat d[AG3(T2AG3)3] G-tetraplex," Structure, vol. 1, no. 4, pp. 263-282, 1993.

[5] Y. Xu, Y. Noguchi, and H. Sugiyama, "The new models of the human telomere d[AGGG(TTAGGG)3] in $\mathrm{K}^{+}$solution," Bioorganic and Medicinal Chemistry, vol. 14, no. 16, pp. 55845591, 2006.

[6] J. Dai, C. Punchihewa, A. Ambrus, D. Chen, R. A. Jones, and D. Yang, "Structure of the intramolecular human telomeric G-quadruplex in potassium solution: a novel adenine triple formation," Nucleic Acids Research, vol. 35, no. 7, pp. 2440 2450, 2007.

[7] A. T. Phan, V. Kuryavyi, K. N. Luu, and D. J. Patel, "Structure of two intramolecular G-quadruplexes formed by natural human telomere sequences in $\mathrm{K}^{+}$solution," Nucleic Acids Research, vol. 35, no. 19, pp. 6517-6525, 2007.

[8] G. N. Parkinson, M. P. H. Lee, and S. Neidle, "Crystal structure of parallel quadruplexes from human telomeric DNA," Nature, vol. 417, no. 6891, pp. 876-880, 2002.

[9] T. Simonsson, P. Pecinka, and M. Kubista, "DNA tetraplex formation in the control region of c-myc," Nucleic Acids Research, vol. 26, no. 5, pp. 1167-1172, 1998.

[10] S. Rankin, A. P. Reszka, J. Huppert, et al., "Putative DNA quadruplex formation within the human c-kit oncogene," Journal of the American Chemical Society, vol. 127, no. 30, pp. 10584-10589, 2005.

[11] J. Dai, T. S. Dexheimer, D. Chen, et al., "An intramolecular G-quadruplex structure with mixed parallel/antiparallel Gstrands formed in the human BCL-2 promoter region in solution," Journal of the American Chemical Society, vol. 128, no. 4, pp. 1096-1098, 2006.
[12] S. Cogoi and L. E. Xodo, "G-quadruplex formation within the promoter of the KRAS proto-oncogene and its effect on transcription," Nucleic Acids Research, vol. 34, no. 9, pp. 25362549, 2006.

[13] S. Neidle, "Human telomeric G-quadruplex: the current status of telomeric G-quadruplexes as therapeutic targets in human cancer," FEBS Journal, vol. 277, no. 5, pp. 1118-1125, 2010.

[14] T.-M. Ou, Y.-J. Lu, J.-H. Tan, Z.-S. Huang, K.-Y. Wong, and L.-Q. Gu, "G-quadruplexes: targets in anticancer drug design," ChemMedChem, vol. 3, no. 5, pp. 690-713, 2008.

[15] J. F. Riou, L. Guittat, P. Mailliet, et al., "Cell senescence and telomere shortening induced by a new series of specific G-quadruplex DNA ligands," Proceedings of the National Academy of Sciences of the United States of America, vol. 99, no. 5, pp. 2672-2677, 2002.

[16] M. Bejugam, S. Sewitz, P. S. Shirude, R. Rodriguez, R. Shahid, and S. Balasubramanian, "Trisubstituted isoalloxazines as a new class of G-quadruplex binding ligands: small molecule regulation of c-kit oncogene expression," Journal of the American Chemical Society, vol. 129, no. 43, pp. 12926-12927, 2007.

[17] A. Siddiqui-Jain, C. L. Grand, D. J. Bearss, and L. H. Hurley, "Direct evidence for a G-quadruplex in a promoter region and its targeting with a small molecule to repress c-MYC transcription," Proceedings of the National Academy of Sciences of the United States of America, vol. 99, no. 18, pp. 1159311598, 2002.

[18] S. L. Palumbo, R. M. Memmott, D. J. Uribe, Y. Krotova-Khan, L. H. Hurley, and S. W. Ebbinghaus, "A novel G-quadruplexforming GGA repeat region in the c-myb promoter is a critical regulator of promoter activity," Nucleic Acids Research, vol. 36, no. 6, pp. 1755-1769, 2008.

[19] S. Cogoi and L. E. Xodo, "G-quadruplex formation within the promoter of the KRAS proto-oncogene and its effect on transcription," Nucleic Acids Research, vol. 34, no. 9, pp. 25362549, 2006.

[20] L. Hayflick and P. S. Moorhead, "The serial cultivation of human diploid cell strains," Experimental Cell Research, vol. 25, no. 3, pp. 585-621, 1961.

[21] M. A. Blasco, "Telomere length, stem cells and aging," Nature Chemical Biology, vol. 3, no. 10, pp. 640-649, 2007.

[22] A. Arora, N. Kumar, T. Agarwal, and S. Maiti, "Retraction: human telomeric G-quadruplex: targeting with small molecules," FEBS Journal, vol. 277, no. 5, p. 1345, 2010.

[23] K. Shin-ya, K. Wierzba, K. Matsuo, et al., "Telomestatin, a novel telomerase inhibitor from Streptomyces anulatus," Journal of the American Chemical Society, vol. 123, no. 6, pp. 1262-1263, 2001.

[24] T. Doi, M. Yoshida, K. Shin-ya, and T. Takahashi, "Total synthesis of (R)-telomestatin," Organic Letters, vol. 8, no. 18, pp. 4165-4167, 2006.

[25] P. S. Shirude, E. R. Gillies, S. Ladame, et al., "Macrocyclic and helical oligoamides as a new class of G-quadruplex ligands," Journal of the American Chemical Society, vol. 129, no. 39, pp. 11890-11891, 2007.

[26] M.-Y. Kim, H. Vankayalapati, K. Shin-ya, K. Wierzba, and L. H. Hurley, "Telomestatin, a potent telomerase inhibitor that interacts quite specifically with the human telomeric intramolecular G-quadruplex," Journal of the American Chemical Society, vol. 124, no. 10, pp. 2098-2099, 2002.

[27] F. Rosu, V. Gabelica, K. Shin-ya, and E. D. Pauw, "Telomestatin-induced stabilization of the human telomeric DNA quadruplex monitored by electrospray mass 
spectrometry," Chemical Communications, vol. 9, no. 21, pp. 2702-2703, 2003.

[28] E. M. Rezler, J. Seenisamy, S. Bashyam, et al., "Telomestatin and diseleno sapphyrin bind selectively to two different forms of the human telomeric G-quadruplex structure," Journal of the American Chemical Society, vol. 127, no. 26, pp. 9439-9447, 2005.

[29] M. Tera, Y. Sohtome, H. Ishizuka, et al., "Design and synthesis of telomestatin derivatives and their inhibitory activity of telomerase," Heterocycles, vol. 69, no. 1, pp. 505-514, 2006.

[30] M. Tera, H. Ishizuka, M. Takagi, M. Suganuma, K. Shin-ya, and K. Nagasawa, "Macrocyclic hexaoxazoles as sequence- and mode-selective G-quadruplex binders," Angewandte Chemie: International Edition, vol. 47, no. 30, pp. 5557-5560, 2008.

[31] M. Tera, K. Iida, H. Ishizuka, et al., "Synthesis of a potent G-quadruplex-binding macrocyclic heptaoxazole," ChemBioChem, vol. 10, no. 3, pp. 431-435, 2009.

[32] G. S. Minhas, D. S. Pilch, J. E. Kerrigan, E. J. LaVoie, and J. E. Rice, "Synthesis and G-quadruplex stabilizing properties of a series of oxazole-containing macrocycles," Bioorganic and Medicinal Chemistry Letters, vol. 16, no. 15, pp. 3891-3895, 2006.

[33] K. Iida, M. Tera, T. Hirokawa, K. Shin-ya, and K. Nagasawa, "G-quadruplex recognition by macrocyclic hexaoxazole (6OTD) dimer: greater selectivity than monomer," Chemical Communications, no. 42, pp. 6481-6483, 2009.

[34] A. De Cian, L. Guittat, M. Kaiser, et al., "Fluorescence-based melting assays for studying quadruplex ligands," Methods, vol. 42, no. 2, pp. 183-195, 2007.

[35] J.-L. Mergny and J.-C. Maurizot, "Fluorescence resonance energy transfer as a probe for G-quartet formation by a telomeric repeat," ChemBioChem, vol. 2, no. 2, pp. 124-132, 2001.

[36] J. Deeley, A. Bertram, and G. Pattenden, "Novel polyoxazolebased cyclopeptides from Streptomyces sp. Total synthesis of the cyclopeptide YM-216391 and synthetic studies towards telomestatin," Organic and Biomolecular Chemistry, vol. 6, no. 11, pp. 1994-2010, 2008.

[37] D. Hernandez, G. Vilar, E. Riego, et al., "Synthesis of IB01211, a cyclic peptide containing 2,4-concatenated thia- and oxazoles, via Hantzsch macrocyclization," Organic Letters, vol. 9, no. 5, pp. 809-811, 2007.

[38] D. Hernandez, M. Altuna, C. Cuevas, R. Aligu, F. Albericio, and M. Alvarez, "Synthesis and antitumor activity of mechercharmycin A analogues," Journal of Medicinal Chemistry, vol. 51, no. 18, pp. 5722-5730, 2008.

[39] M. Kunishima, C. Kawachi, F. Iwasaki, K. Terao, and S. Tani, "Synthesis and characterization of 4-(4,6-dimethoxy-1,3,5triazin-2-yl)- 4-methylmorpholinium chloride," Tetrahedron Letters, vol. 40, no. 29, pp. 5327-5330, 1999.

[40] P. Balagurumoorthy and S. K. Brahmachari, "Structure and stability of human telomeric sequence," Journal of Biological Chemistry, vol. 269, no. 34, pp. 21858-21869, 1994.

[41] F. Rosu, V. Gabelica, C. Houssier, P. Colson, and E. D. Pauw, "Triplex and quadruplex DNA structures studied by electrospray mass spectrometry," Rapid Communications in Mass Spectrometry, vol. 16, no. 18, pp. 1729-1736, 2002.

[42] H. Li, Y. Liu, S. Lin, and G. Yuan, "Spectroscopy probing of the formation, recognition, and conversion of a G-quadruplex in the promoter region of the bcl-2 oncogene," Chemistry European Journal, vol. 15, no. 10, pp. 2445-2452, 2009. 

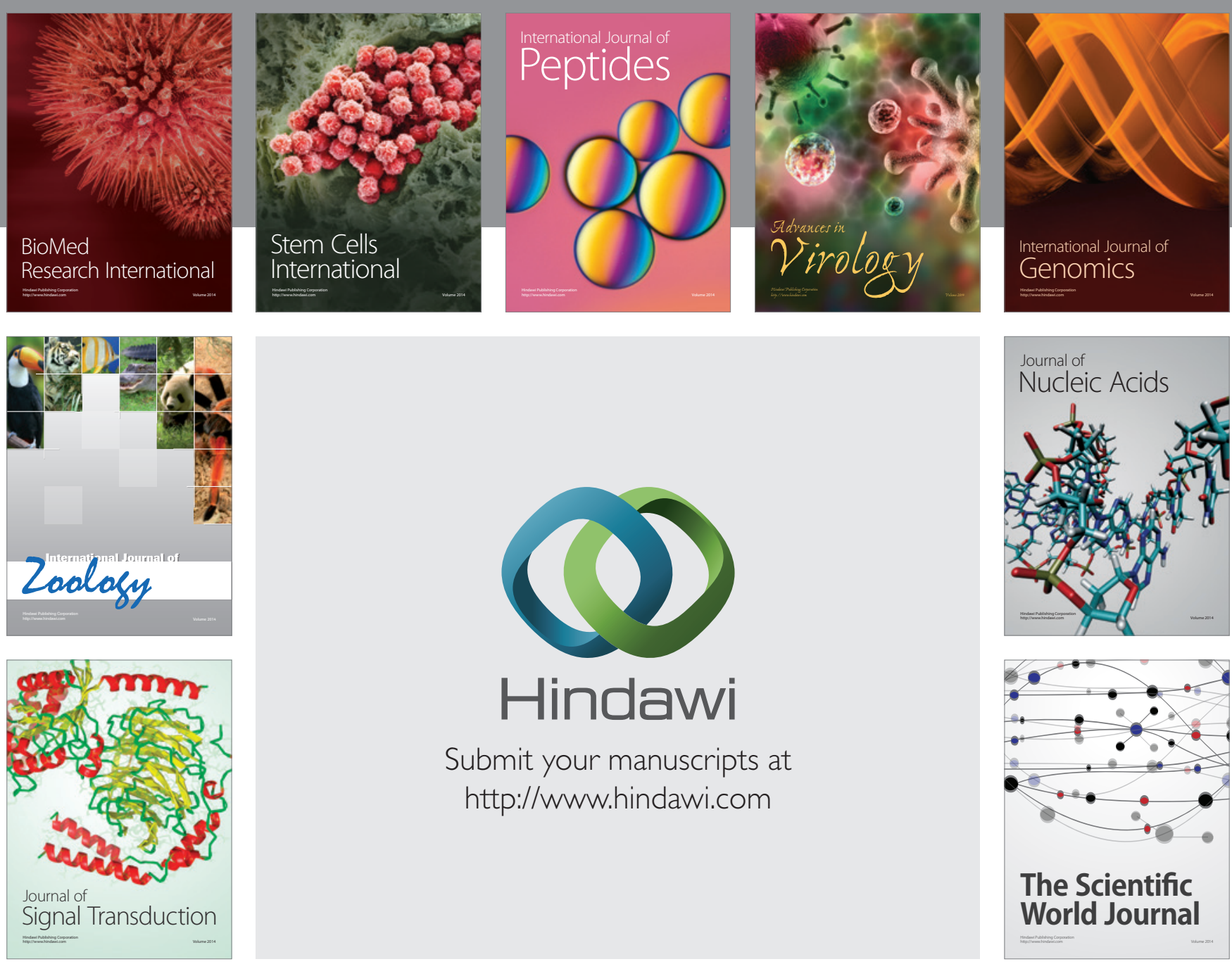

Submit your manuscripts at

http://www.hindawi.com
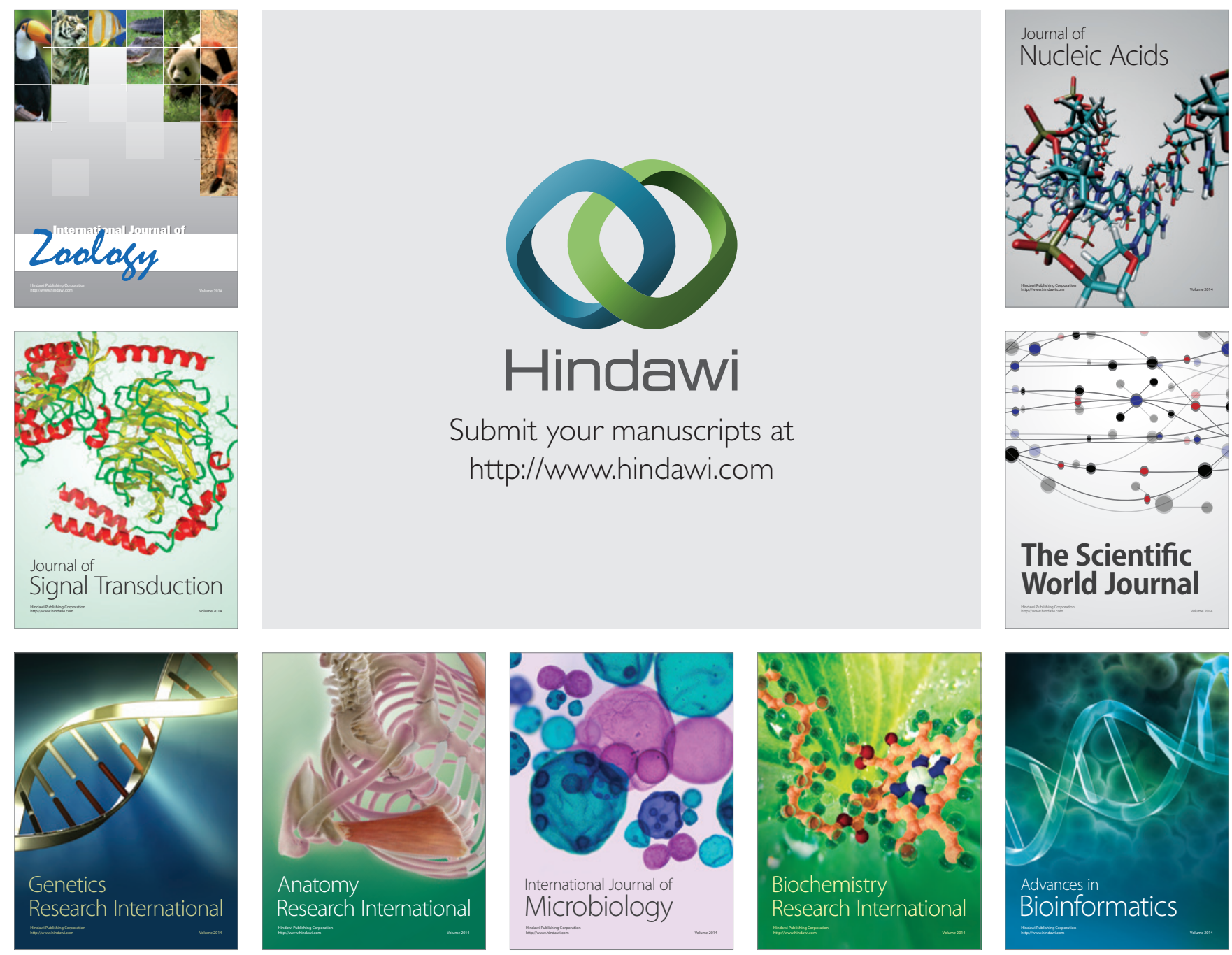

The Scientific World Journal
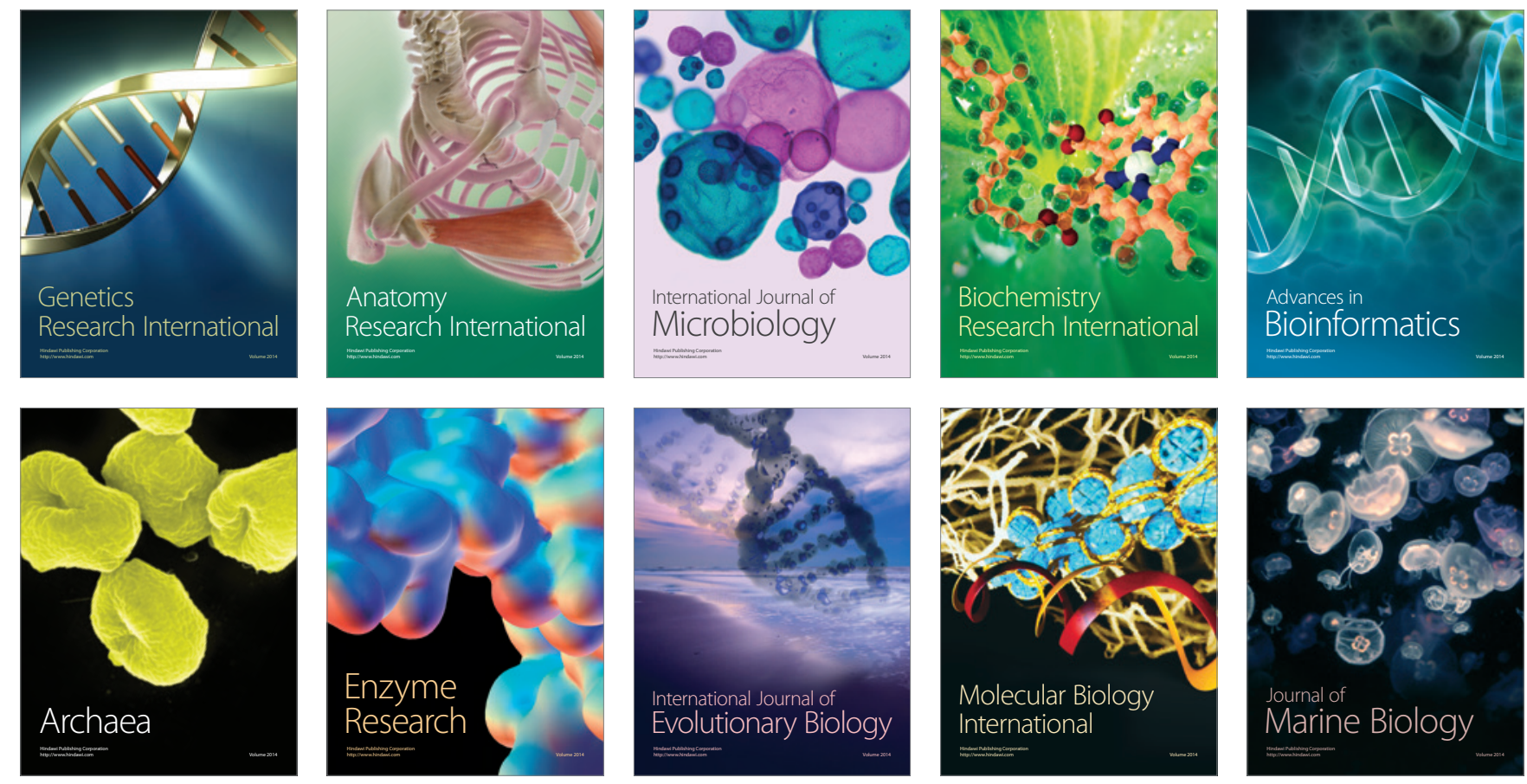